\title{
Nurse-midwives reconfiguring care in the scope of labor and births in COVID-19 times
}

\author{
Enfermeiras obstétricas reconfigurando o cuidado no âmbito do parto e nascimento em tempos de COVID-19
}

Matronas reconfigurando el cuidado en el marco de nacimiento y parto en tiempos de COVID-19

Paolla Amorim Malheiros Dulfe' ORCID: 0000-0003-1653-4640

Valdecyr Herdy Alves' ORCID: 0000-0001-8671-5063

Audrey Vidal Pereira' ORCID: 0000-0002-6570-9016

Bianca Dargam Gomes Vieira' ORCID: 0000-0002-0734-3685

Diego Pereira Rodrigues" ORCID: 0000-0001-8383-7663

Giovanna Rosário Soanno Marchiori' ORCID: 0000-0002-0498-5172

Maria Bertilla Lutterbach Riker Branco' ORCID: 0000-0002-5117-644X

'Universidade Federal Fluminense. Niterói, Rio de Janeiro, Brazil. "Universidade Federal do Pará. Belém, Pará, Brazil.

How to cite this article: Dulfe PAM, Alves VH, Pereira AV, Vieira BDG, Rodrigues DP, Marchiori GRS, et al. Nurse-midwives reconfiguring care in the scope of labor and births in COVID-19 times. Rev Bras Enferm. 2021;74(Suppl 1):e20200863. doi: http://dx.doi.org/10.1590/0034-7167-2020-0863

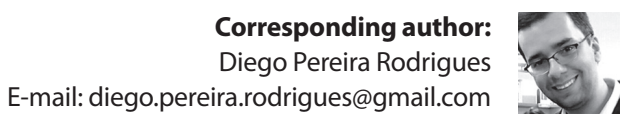

EDITOR IN CHIEF: Dulce Barbosa ASSOCIATE EDITOR: Ana Fátima Fernandes

Submission: $08-13-2020$

Approval: $12-06-2020$

\section{ABSTRACT}

Objectives: to analyze how the nurse-midwives of maternity wards that were fields of practice for an improvement course in obstetrics have reorganized care in the context of labor and birth amidst the COVID-19 pandemic. Methods: this is a descriptive, exploratory and qualitative study carried out with nine nurse-midwives who are preceptors and collaborators in maternity wards that were fields of practice for an improvement course, between February and April 2020, through a semi-structured interview through WhatsApp. Content analysis was used to treat the information. Results: the pandemic brought the need to reorganize work, with a focus on service training and maintenance of good practices in labor and birth, whose movement was intensely experienced, interfering in nurse-midwives'mental health. Conclusion: nurse-midwives have faced the pandemic with concerns about maintaining safe care, focused on practices based on updated scientific evidence.

Descriptors: Obstetric Nursing; Nursing Care; Pregnant Women; Pandemics; Coronavirus Infections.

\section{RESUMO}

Objetivos: analisar como as enfermeiras obstétricas das maternidades que foram campos de prática de um curso de aprimoramento em obstetrícia têm reorganizado o cuidado no âmbito do parto e nascimento em meio à pandemia de COVID-19. Métodos: estudo descritivo, exploratório e qualitativo, realizado com nove enfermeiras obstétricas preceptoras e colaboradoras em maternidades que foram campos de prática de um curso de aprimoramento, entre fevereiro e abril de 2020, por meio de entrevista semiestruturada através do aplicativo WhatsApp. Utilizou-se a técnica de análise de conteúdo para o tratamento das informações. Resultados: a pandemia trouxe a necessidade de reorganizar o trabalho, com foco na capacitação em serviço e manutenção das boas práticas no âmbito do parto e nascimento, cujo movimento foi vivenciado intensamente, interferindo na saúde mental das enfermeiras obstétricas. Conclusão: as enfermeiras obstétricas têm enfrentado a pandemia com preocupações em manter assistência segura, focada nas práticas baseadas em evidências científicas atualizadas. Descritores: Enfermagem Obstétrica; Cuidados de Enfermagem; Gestantes; Pandemias; Infecções por Coronavírus.

\section{RESUMEN}

Objetivos: analizar cómo matronas de maternidad que fueron campos de práctica para un curso de perfeccionamiento en obstetricia han reorganizado la atención en el contexto del parto y parto en medio de la pandemia de COVID-19. Métodos: estudio descriptivo, exploratorio y cualitativo, realizado con nueve matronas, preceptoras y colaboradoras en maternidades que fueron campos de práctica para un curso de perfeccionamiento, entre febrero y abril de 2020, mediante entrevista semiestructurada a través de WhatsApp. Para el tratamiento de la información se utilizó la técnica de análisis de contenido. Resultados: la pandemia trajo la necesidad de reorganizar el trabajo, con foco en la formación en servicio y mantenimiento de buenas prácticas en el ámbito del parto y parto, cuyo movimiento se vivió intensamente, interfiriendo en la salud mental de las matronas. Conclusión: las matronas han enfrentado la pandemia con inquietudes por mantener una atención segura, enfocadas en prácticas basadas en evidencia científica actualizada. Descriptores: Enfermería Obstétrica; Atención de Enfermería; Mujeres Embarazadas; Pandemias; Infecciones por Coronavirus. 


\section{INTRODUCTION}

The World Health Organization (WHO) declared, on March 11, 2020, the pandemic situation due to SARS-CoV-2 (COVID-19). Since then, the spread of the virus continues to increase globally, reaching an alarming amount across the planet. WHO has endeavored to publish scientific evidence and guidelines to assist countries in controlling the pandemic, pointing to the need for populations to have universal access to essential services of life, such as health services ${ }^{(1-2)}$.

In this line of coping with the pandemic, Brazil, through the Ministry of Health (MoH), on February 4, 2020, officially decreed a health emergency for the entire national territory, aiming to anticipate actions to control and combat COVID-19. This process involved the restructuring of health units - including implementation of beds, human resources, equipment and personal protection materials ${ }^{(3)}$ - and the recommendations for social distance, isolation of contaminated people, closing of shops, measures to control entry and exit from the country ${ }^{(4)}$. However, in spite of the measures adopted, the process of contamination and lethality of the disease advanced rapidly, surpassing 5.5 million people infected and more than 161 thousand killed on October 6, 2020 $0^{(1,5)}$.

The new coronavirus has shown a high prevalence in elderly men and people with comorbidities, such as diabetes, hypertension, heart disease, obesity, kidney and respiratory diseases, characterizing greater vulnerability for certain groups ${ }^{(2,6-10)}$. Pregnant women and puerperal women have also been classified as a risk group, because, in addition to being susceptible to infection, they are also likely to develop into serious complications such as coagulopathies and vertical transmission ${ }^{(11-14)}$.

However, in the reproductive health field, the United Nations (UN) and the MoH point out that health precautions, guidelines and conduct recommended for this group, in addition to monitoring the specificities of the group considered at risk, should be the same aimed at the general population, such as physical distance, isolation of symptomatic people (coughing or sneezing), washing hands frequently with soap and water or using $70 \%$ alcohol, and using a mask and eye protector ${ }^{(15-16)}$.

As it is a group considered to be at risk, there continues to be a context of insecurities and the need to monitor the specificities of women's health, since they are in situations of vulnerability. So far, there are no specific pandemic control measures in the world.

In terms of care during labor and birth, nurse-midwives have also faced changes in their work context that can directly affect women's health care. Thus, the need to plan and implement interventions in order to provide effective, safe and qualified care to women and newborns is justified, considering that it is a risk group, especially in pandemic times, as human rights have a tendency to be less protected, disproportionately impacting women's health ${ }^{(6,17)}$.

As labor and birth in Brazil still predominate in spaces similar to the hospital context, there is a need to pay attention to safety and protection measures for women and newborns (with suspected or confirmed diagnosis of COVID-19) that can alter the entire work process of nurse-midwives. Even though it is necessary to take into account the specificities of the maternal and child field, actions must be conducted in general in accordance with
WHO recommendations. Practices based on updated scientific evidence, isolation for diagnosed patients should be included, regardless the presence of signs of worsening ${ }^{(2-3,18-20)}$.

Considering the context that does not yet have specific measures to control the pandemic, such as vaccines and an effective treatment protocol, there is a need to intensify conduct based on surveillance and health care, in this case, women and newborns ${ }^{(14)}$. In this context, nursing-midwifery needs to reframe changes related to professional performance, as work processes are directly affected by the pandemic.

This new context has changed the work reality of nursemidwives where the Nursing-Midwifery Improvement Course took place, funded by the MoH between 2018 and 2020 (CAEO/ $\mathrm{MoH} / \mathrm{UFF}$ ). This fact interferes with nurse-midwives' work in these contexts, which were and continue to be important spaces for training and qualification, as well as nurse-midwives' mental health, including during crisis situations, such as those experienced during the COVID-19 pandemic ${ }^{(21)}$.

\section{OBJECTIVE}

To analyze how the nurse-midwives of maternity wards that were fields of practice for an improvement course in obstetrics have reorganized care in the context of labor and birth amidst the COVID-19 pandemic.

\section{METHODS}

\section{Ethical aspects}

This study was approved by the Research Ethics Committee of Hospital Universitário Antônio Pedro of Universidade Federal Fluminense, as provided for Resolution 466/2012 of the Brazilian National Health Council (Conselho Nacional de Saúde). In order to preserve the respective secrecy, anonymity and reliability, the interviewees received an alphanumeric coding (e.g., NM1, NM2, NM3,..., NM9), in addition to the guarantee of voluntary participation by signing the Informed Consent Form (ICF).

\section{Type of study}

This is a descriptive, exploratory study with a qualitative approach, adopting the Consolidated Criteria for Reporting Qualitative Research (COREQ) ${ }^{(22)}$, which aims at quality and transparency of qualitative health research. Participants were nurse-midwife preceptors and collaborators of maternity wards that were fields of practice of the Enhancement Course for Nurse-Midwives (CAEO - Curso de Aprimoramento para Enfermeiras Obstétricas), funded by the $\mathrm{MoH}$ and carried out by Escola de Enfermagem Aurora de Afonso Costa of Universidade Federal Fluminense (CAEO/MoH/UFF).

CAEO, with a focus on labor and birth (CAEO/APICEON/MoH), is financed from the MoH/UFF/PROPLAN/FEC Project, celebrated between the National Health Fund, the Executive Department and the $\mathrm{MoH}$. The course reached an audience of 64 nurse-midwives in Brazil, distributed in seven classes between 2018 and 2019. Nurse-midwives (NMs) were immersed for 15 (fifteen) days in two maternity hospitals in the state of Rio de Janeiro. This course 
proposes to expand the teaching-service integration, qualifying both care practices and professional training, focusing on changing the model of care for labor and birth, including the insertion and strengthening of nursing-midwifery performance in the assistance of habitual risk delivery.

\section{Study setting}

The setting comprised two public maternity hospitals in Rio de Janeiro, one linked to the Municipal Health Department (MHD$\mathrm{RJ}$ ) and the other to the Municipal Health Foundation of Niterói, which were fields of practice for CAEO/MoH/UFF.

\section{Data collection and organization}

Nine NMs working in the maternity hospitals where the theoretical and practical teaching of CAEO/MoH/UFF participated in the study. NMs preceptors and collaborators of the improvement course and with specialist enrollment in the Regional Nursing Council (Conselho Regional de Enfermagem) of Rio de Janeiro were included. Nurses who were licensed for health reasons were restricted. Thus, of the ten eligible, nine NMs participated, as one was on sick leave for positive testing for COVID-19, being excluded from the study.

With respect to Ordinance 65 of March 16, 2020 from the Ministry of Economy ${ }^{(23)}$, which institutes the non-holding of oneto-one meetings, and due to local state and municipal actions that restrict movement between municipalities in the state of Rio de In January, participants were invited to compose the study through telephone contact, made available by the management of maternity hospitals, then through WhatsApp'. The sample was delimited by convenience, through contact via message through the application, sent by the main researcher and inviting them to participate in the research. Professionals who expressed availability and interest were included in the study.

The investigation path used a semi-structured interview, with questions related to how is obstetric practice of professionals in COVID-19 times. The data were collected between February and April 2020, individually, by the main researcher through WhatsApp'. Due to the exceptionality of the historical moment, considering the need to welcome participants and the change in work routines caused by the pandemic, the interview questions were sent to each participant. They answered in a timely manner, with an average duration of 15 minutes each, allowing participants to investigate the reorganization process in caring for women and newborns within labor and birth in the COVID-19 pandemic times. The testimonials stored by means of their messages and/or audio in the application were transcribed in full, to succeed to material treatment.

\section{Data analysis}

Data analysis sought treatment based on content analysis in the thematic modality, with the objective of discovering the nuclei of meaning, whose established phases were: 1) pre-analysis of statements; 2 ) material exploration and treatment of results; 3 ) inference and interpretation ${ }^{(24)}$.
For material organization and coding, simple computerized resources (colorimetry in Microsoft Word ${ }^{\circ}$ ) were used, which made it possible to elect the Registration Units (RUs): changes in NMs' performance; protocols and reorganization of health work; health training in COVID-19 times; Personal Protective Equipment (PPE). The following thematic core was listed: reframing the work processes of NMs in COVID-19 times, which justified constructing the following categories: 1) Reconfiguring nurse-midwives' work in COVID-19 times; 2) In-service training, pandemic and the affected nurse-midwives' mental health.

\section{RESULTS}

\section{Reconfiguring nurse-midwives' work in COVID-19 times}

The challenges imposed on health services during coping with the pandemic showed the need to reconfigure the work process, taking into account the consequences of the new coronavirus and the specificities related to labor and birth. In this sense, there was a movement to realign the actions carried out by NMs, in an attempt to adapt to the guidelines of official bodies (emphasis on $\mathrm{WHO}$ ) and to support updated scientific evidence. Such a process can be exemplified from the following statements:

Throughout this month of March, this was adjusted [...] each day was a new thing: it couldn't be like this, it could be like that. The protocols were arriving daily and we adjusted these flows daily. (NM1)

At the moment, everything is very new, and the guidelines have been changing all the time [...] working with good practices as far as possible is what we continue to follow, as long as it does not bring any risk to pregnant women, companions and professionals. (NM5)

First, which is a very new thing, that we have nothing ready, right?! We end up taking a little of the experience of other countries. We read, but some things do not fit our reality, so we adapt [...] to our reality, to our physical structure. (NM6)

Obstetric practice has been adapted to each new recommendation by the Ministry of Health, always seeking greater security for women and babies, and for professionals who are directly in care. (NM9)

Thus, the NMs located in the maternity wards that were fields of practice for CAEO/MoH/UFF demonstrated an intense search to appropriate the new knowledge produced in the country and in the world, reorganizing the work process in sharing with other health professionals and the service management itself. In general, the ordering and qualification of flows and actions in obstetric services was observed, reorienting protocols based on national and international recommendations in order to optimize the use of available care resources and promote integrality and equity in access to health actions. To this end, the services have appropriated operational guidelines and regulatory protocols.

We held several meetings, the board gathered all the heads, the $\mathrm{CCIH}$, the security unit. [...] we made an isolation room on admission, the protocols, step by step. We have, in all sectors, we 
have an isolation area, all these areas have flows, flows distributed by WhatsApp to everyone, printed in all units, in all sectors. (NM1)

The flows were built, but still with a lot of change daily, right? Today we were "there" readjusting a series of things that the last publication of the Ministry of Health now of the $10^{\text {th }}$ [April] in the technical note. (NM3)

There was the establishment of a flowchart also related to symptomatic patients who arrive at the maternity hospital. (NM4)

An important aspect punctuated by NMs involves the concern to avoid the contamination and spread of COVID-19 among women and babies, health professionals, and companions. There is a reassessment of obstetric care routines in order to prevent risks and control contagions of the disease. To this end, standard precautionary measures were implemented in caring for pregnant women, puerperal women and newborns, extending to contacts with companions and the team itself. Thus, there was a redesign in the structural organization and hospital routines, especially regarding the use of PPE (surgical mask, gloves, eye protection, and apron) in maternity services, as described below:

Here we are trying to make an early discharge, to speed up the discharge of these women as much as possible, but trying to take a little more care in these guidelines, because, for them, there is also a recommendation at home for isolation, for a more solitary protection, in sense of protection for her and babies [...] as well as assistance, to reduce the circulation of personnel also inside the boxes. (NM3)

I think the difficulties are more in relation to shared care. The births, which are with nursing-midwifery, we have only really dressed up. If it is not symptomatic, standard precaution, droplet contact, and if it is symptomatic, we put on the N95 and put on the apron and try to decrease the maximum flow of people inside the delivery room. I ask the technician [nursing] only to enter after birth, for the pediatrician to enter as soon as the baby is born, try not to change the companion. Always leave the same companion with the woman, to avoid this change of companion. At the maternity hospital, visits were also suspended. (NM8)

The course for screening this pregnant woman was reformulated, as well as the use of PPE [personal protective equipment] in this case. (NM7)

Thus, it became evident the need for a movement against time, to reorganize the obstetric care services, with NMs active in carrying out the CAEO/MoH/UFF in the maternity hospitals, which were involved in guaranteeing processes of discussion at work. In this guiding line, it is worth pointing out that the good care practices of women and babies based on updated scientific evidence were present in team meetings, whose management support proved to be decisive to ensure processes of changes related to the pandemic without losses to quality and health care security.

A patient who has a respiratory symptom of the flu or cold is advised to wear a mask during hospitalization. But, if she has signs and symptoms for COVID-19 [...] we have a specific ward to be able to leave her [...] that's it, the practice remains the same, but increased care for the use of a mask, hand hygiene and the lack of a companion in the environment. (NM2)

This patient, arriving at the maternity ward, she would be placed at the reception with a surgical mask, and then she would be sent to a room set up especially for the care, reception, risk classification and medical care. (NM4)

\section{In-service training, pandemic and the affected nurse- midwives' mental health}

In-service training was one of the activities that stood out the most, as it was associated with the urgent need to implement new knowledge in the work dynamics. It requires a process of deconstruction and re-elaboration of actions; in this case, in obstetrics, that even in contradictory and challenging moments, have the capacity to guarantee quality and safety of health care for women in reproductive phase. However, more evidently, the possibility of contagion affects massively health professionals themselves. A little of this issue appears in the following statements:

In relation to the practice with the coronavirus, we have been protecting ourselves a little more. The births I have assisted, I have used gloves, masks, caps. I will be honest with you, I have not worn the apron [...] / was actually reading and everything [...] / am maintaining standard contact and droplet precautions, so I wear a mask. (NM8)

Considering the ways of doing and knowing, with a view to updating care practices with a view to guaranteeing protection for professionals, NMs sought strategies based on: in-service training processes; ways to ensure proper handling of information; correct identification of suspected cases; attention to the health of women and newborns, with ethics and commitment, with institutional isolation measures, in order also to maintain working conditions of the team itself:

We split up to do these trainings[...] producing a video of proper dressing and dressing for all teams, nursing staff, medical staff, anesthesia staff, all, because it is a crucial moment of contamination by the health professional. (NM1)

Today, I can tell you that we know what to do when a woman with suspected COVID-19 arrives. [...] it was a very big challenge until recently. Some specific recommendations for maternity came out. Then, as we had half, almost $80 \%$ walked, we just adapted the recommendations that we were receiving, removing doubts [...] always showing themselves available for doubts, so that no one would come in and be scared, scared by everything that is happening. (NM6)

The issues raised by NMs throughout the illustrations reflect concern about contagion in COVID-19 management. Thus, in the midst of work overload, the urgency for successive training of teams and a decrease in the number of team professionals, the process of anguish and fears has grown, directly influencing the work dynamics of NMs:

As it is a crucial moment of contamination by the health professional, so we have been discussing with the teams for a long time. All this time, doing all of this together at the same time. For this reason it was very tiring, exhausting weeks. (NM1) 
In addition to the huge demand for work [...] / am very overwhelmed, I am alone doing a lot of things. [...] several and very delicate situations. [...] we are trying, making an absurd effort to take good care. That's it, I have more questions than answers, I know, but I believe that this was the anguish and reality of several teams. (NM3)

We are struggling to change and still in this context provide human assistance in the midst of chaos. (NM7)

We are going through a distressing and worrying situation. I am afraid of being on duty and being contaminated by contact with my own co-workers who work elsewhere. I try to continue offering my best care to the families we attend at the maternity hospital, but, certainly, if I had the choice, I would not be going to work. (NM9)

Thus, in the face of unusual situations experienced in the midst of impermanence of information on all continents, the NM team went through difficult moments in relation to reorganizing the work process in the face of reality. Such reorganization not only required permanent training in service, but also needed to maintain positions of welcome and listening to the obstetric nursing team itself.

\section{DISCUSSION}

In this context of a pandemic, in which the routine of health services has been affected, it has been opportune to reflect on how NMs' practice has been carried out in maternity wards that were fields of practice for the CAEO/MoH/UFF, mainly because it is a professional group committed to health care for women and newborns during the COVID-19 pandemic ${ }^{(20)}$.

In the meantime, reflections are raised, important challenges for work, which occur in the daily health care ${ }^{(25)}$, making NMs, in the reproductive health fields, remain implicated in work reorganization processes to in order to care for women and newborns who can find themselves in situations of vulnerability ${ }^{(26-27)}$.

In Brazil, different measures have been adopted in an attempt to contain the increase in the number of SARS-CoV-2 infections. The $\mathrm{MoH}$, the Federal Nursing Council (COFEN - Conselho Federal de Enfermagem) and the Brazilian Association of Obstetricians and Nurses-Midwives (ABENFO - Associação Brasileira de Obstetrizes e Enfermeiros Obstetras), through different departments, have been joining efforts to reorient and reorganize health services for the qualified care of patients with suspected or confirmed diagnosis of COVID-19. Among these measures are the Brazilian National Contingency Plan for Human Infection with the New Coronavirus, coordinated by the Health Surveillance Department (HSD) ${ }^{(3)}$.

Currently, it is known that undetected and asymptomatic cases are the main responsible for the high transmission rate of COVID-19 ${ }^{(28)}$, which presents itself as an important node in a country with continental characteristics, whose access to testing disease has still presented itself in a limited way. Therefore, with the vision of in-service education and training, in dialogue with processes experienced during CAEO/MoH/UFF, the NMs contributed significantly so that the work process could be reorganized in the face of chaos, without losing an attentive look at security based on scientific evidence in line with humanization and service quality.
Furthermore, it is noteworthy that the health units involved did not go to great lengths to make adjustments according to national and international recommendations, with a view to minimizing the exponential spread of the disease, reducing the burden on health systems and preventing the pandemic expansion ${ }^{(3,18-19)}$.

Bearing in mind that the guarantee of human and women's rights in the field of reproductive health is permanent, the Unified Health System (SUS - Sistema Único de Saúde) presents programs and policies that encourage NMs' direct action in caring for women in the reproductive period. It is reaffirmed in pandemic times that professionals' performance is decisive for control ${ }^{(29-30)}$.

Thus, NMs' performance could, to some extent, favor support for reorganizing the work process. These professionals are directly responsible for optimizing available resources to continue qualifying health care for women even in COVID-19 times.

Thinking and acting in the reformulation of work processes proved to be essential in pandemic times, especially in the work of nursing-midwifery. Expanding the dimensions of health care, which are part of regulation of health systems in their territory, of women's health care in maternity hospitals and their access to assistance, which could meet the specificities of the population group, was a challenge present in dynamics developed by NMs during the pandemic.

The work process operationalization for NMs was based on a set of pre-established rules in institutions that, during the pandemic, needed rapid changes and collective action in order to guarantee quality and safety care processes ${ }^{(25)}$. However, as noted, the rules, flows and protocols had no possibility of remaining static, requiring reinventions to cover the changes produced after the advent of COVID-19(31). Work means the production of knowledge that remains in close relationship with the demands and situations experienced in the daily services' dynamic reality. Thus, strategies were created that sought, to some extent, to maintain a dialogue with the updated scientific bases ${ }^{(25)}$.

Thus, NMs of maternity hospitals that were fields of practice for the improvement course in obstetrics financed by the $\mathrm{MoH}$ had, once again, the opportunity to experience in-service training strategies that dialogue with analysis and intervention processes at work, the consequences of which enabled optimize changes that presented meaning to the group of workers. The health field is characterized as an essential teaching and training territory, articulating learning that encompasses ways of knowing and doing in health, seeking to bring health care, management and training professionals together ${ }^{(25-26,32)}$. Such knowledge is linked to the daily routine of NMs located in maternity wards that were fields of practice for CAEO/MoH/UFF, subsidizing the possibility of reorienting modes of care even in the face of adverse situations, such as the COVID-19 pandemic.

In addition to the activities to reorganize flows and protocols, NMs effectively carried out health education actions directed at women and especially at companions. They were shown to have a fundamental role in care actions, qualifying processes that, even before the limitation of the number of people in institutional spaces, were possible to guarantee, to some extent, humanized actions.

Thus, the official recommendations were that women and companions in maternity wards should be advised about preventive 
measures to combat COVID-19, such as: covering the mouth and nose with the forearm or with disposable tissues when coughing or sneezing; wash your hands with $70 \%$ alcohol or wash them with soap and water periodically or anytime immediately after coming in contact with secretions; keep women with flu-like symptoms or suspected contamination by COVID-19 in isolation, so that anyone who comes in contact with her would use appropriate PPE ${ }^{(3,33)}$.

In addition, reorganizing the physical assistance spaces for women, newborns and caregivers in the health unit emerged as a permanent concern of NMs in the maternity wards that were the practice areas of CAEO/MoH/UFF, with changes in attitudes in reconfiguration of obstetric services. Ideally, women who were suspected or confirmed by COVID-19 should be placed in individual spaces ${ }^{(3)}$. These attitudes of reconfiguring care provided greater security for the work and care process, both for women and companions and for the team itself.

The concern with contagion during the pandemic was present in all social spaces, especially in health institutions where workers needed to adopt strict measures of individual protection and consequently the entire population. In this sense, NMs who worked directly in the maternity wards needed to articulate processes that guarantee safe care, but also enable in-service training processes that could carry out uniform actions and information in the daily work routine, even in times of uncertainty and personal and professional insecurities.

In this time of pandemic, these professionals were fighting a tough battle against an invisible agent who threatens and keeps the entire team overwhelmed. In-service training can be one of the main paths to health care safety, and its process is a challenge in institutions, as the need to bring direct assistance professionals and managers together can qualify processes and expand SUS guidelines ${ }^{(25-26)}$, even in pandemic times.

The Centers for Disease Control and Prevention ${ }^{(18)}$ recommendations for health establishments that provide obstetric care, reinforce the importance of performing, in addition to isolating patients and adequate use of PPE, basic training and permanent updating for all professionals promoting the implementation of adequate infection control. This in-service training was carried out by NMs located in maternity wards that were fields of practice for $\mathrm{CAEO} / \mathrm{MoH} / \mathrm{UFF}$, making it possible to ensure team dialogues and contribute to the protection of the lives of health professionals' who were on the front lines of fighting the pandemic.

In this way, in-service training should be seen as the power of collective production $^{(32)}$, through the reciprocal intervention in health professionals and services, built in the daily work ${ }^{(25-26,32)}$. In this context, these NMs are established as protagonists in the commitment to reorient health practices that promote safe and qualified care for women and newborns in the context of COVID-19.

The results of this study, from the statements of these NMs, showed an urgency to expand knowledge to care for people infected by COVID-19, especially in the area of women's health, which has specificities. Empowering both the nursing team and other health professionals was experienced by NMs amid the feeling of collective responsibility to protect life.

Thus, in times of uncertainty about how to face the pandemic, these professionals needed to reinvent processes continuously, whose actions go through intensification and work overload, different scales with a deficit of team professionals, accumulated responsibility before the need to intensify in-service training in pandemic times. Moreover, situations considered stressful, due to risks of contagion and transmission, needed to be contextualized, taking into account the constant presence of fears and professional insecurities, which, in turn, directly affected mental health ${ }^{(21)}$.

The care for the population assisted in maternity hospitals and the need for constant surveillance in the processes of professional activity during the pandemic have made the NMs work under pressure. As a result, high levels of anxiety were generated, the consequences of which, faced with successive situations considered stressful, characterized the possibility of having mental health affected ${ }^{(34-35)}$.

\section{Study limitations}

Among the limitations for conducting this study was the impossibility of triangulating data with records produced by NMs in health services.

\section{Contributions to nursing}

It is noteworthy that the care provided by NMs is an essential activity performed for the population. Thus, the organization of obstetric services, even in times of the COVID-19 pandemic, must be the object of both nurses and other team professionals and health service managers

\section{FINAL CONSIDERATIONS}

The actions experienced by the NMs in the maternity wards that were fields of practice of the improvement course in obstetrics funded by the MoH (2018-2020) ended up influencing the ways of reorganizing the work process during the pandemic, whose processes were carried out based on recommendations $\mathrm{WHO}$ and $\mathrm{MoH}$. Meeting the specificities related to women's health and reorienting practices to ensure control of the pandemic was a movement led by NMs, whose focus was directed to the responsibility of maintaining the humanization process and carrying out practices based on scientific evidence in the context of obstetric care.

In the case of this study, NMs enabled responsible involvement in the process of redirecting flows, re-elaborating protocols, organizing spaces for isolation, participating in meetings with the unit's management and training workers. These were activities aimed at ensuring health protection for women, newborns, family members and the team itself in COVID-19 times.

Thus, in the midst of rapid changes and risks of contagions and transmissions, NMs have faced the pandemic, experiencing concerns about maintaining quality assistance, humanization, security and scientific basis. In-service training was necessary to ensure continuity of care and information flow between professionals and teams. However, uncertainties and impermanences in processes and information during this specific moment of the pandemic have interfered in the care of women, newborns and companions. In large part, this process has been crossed by fears, anxieties and situations that are considered stressful, which, in turn, characterize work overload, affecting NMs' mental health. 


\section{FUNDING}

Research originated from a project financed by the Ministry of Health, Brazil (n³969/2018) and operated by Universidade Federal Fluminense/Fundação Euclides da Cunha, during the years 2018/2019.

\section{ACKNOWLEDGMENT}

We thank the participating NMs for having contributed to the construction of knowledge in the midst of reconfiguring the care processes for women and newborns during the COVID-19 pandemic.

\section{REFERENCES}

1. World Health Organization (WHO). Coronavírus disease 2019 (COVID-19) pandemic [Internet]. Geneva: WHO; 2020 [cited 2020 Jul 01]. Available from: https://www.who.int/emergencies/diseases/novel-coronavirus-2019

2. Cummings MJ, Baldwin MR, Abrams D, Jacobson SD, Meyer BJ, Balough EM, et al. Epidemiology, clinical course, and outcomes of critically ill adults with COVID-19 in New York City: a prospective cohort study. Lancet. 2020;395(10239):1763-70. https://doi.org/10.1016/ S0140-6736(20)31189-2

3. Ministério da Saúde (BR). Protocolo de manejo clínico para o novo coronavírus (19-nCov) [Internet]. Brasília: Ministério da Saúde; 2020 [cited 2020 Jul 01]. Availablefrom:https://www.arca.fiocruz.br/handle/icict/40249

4. Ministério da Saúde (BR). Lei no 13.979, de 6 de fevereiro de 2020. Dispõe sobre as medidas para enfrentamento da emergência em saúde pública de importância internacional decorrente do coronavírus responsável pelo surto de 2019 [Internet]. Diário Oficial da União, seção 1 , p. 1, 2020 [cited 2020 Jul 01]. Available from: http://www.in.gov.br/en/web/dou/-/lei-n-13.979-de-6-de-fevereiro-de-2020-242078735

5. Johns Hopkins University. Center for Systems Science and Engineering (CSSE)[Internet]. Baltimore: MD: CSSE; 2020 [cited 2020 Nov 06]. Available from: https://coronavirus.jhu.edu/map.html

6. Hall KS, Samari G, Gabers S, Casey SE, Diallo DD, Moresky RT, et al. Centring sexual and reproductive health and justice in the global COVID-19 response. Lancet. 2020;395(10231):1175-7. https://doi.org/10.1016/S0140-6736(20)30801-1

7. Conti P, Younes A. Coronavirus COV-19/SARS-CoV-2 affects women less than men: clinical response to viral infection. J Biol Regul Homeost Agents. 2020;34(2):10.23812. https://doi.org/10.23812/editorial-conti-3

8. Wu JT, Leung K, Leung GM. Nowcasting and forecasting the potential domestic and international spread of the 2019-nCoV outbreak originating in Wuhan, China: a modelling study. Lancet. 2020;395(10225):689-97. https://doi.org/10.1016/S0140-6736(20)30260-9

9. Simonnet A, Chetboun M, Poissy J, Raverdy V, Noulette J, Duhamel A, et al. High prevalence of obesity in severe acute respiratory syndrome coronavirus-2 (SARS-CoV-2) requiring invasive mechanical ventilation. Obesity (Silver Spring). 2020;28(7):1195-99. https://doi.org/10.1002/ oby. 22831

10. Wenham C, Smith J, Morgan R. COVID-19: the gendered impacts of the outbreak. Lancet. 2020;395(10227): 846-8. https://doi.org/10.1016/ S0140-6736(20)30526-2

11. McDonald ES. COVID-19 and essential pregnant worker policies. Lancet. 2020. https://doi.org/10.1016/ S1473-3099(20)30446-1

12. Zeng L, Xia S, Yuan W, Yan K, Xiao F, Shao J, et al. Neonatal early-onset infection with SARS-CoV-2 in 33 neonates born to mothers with COVID-19 in Wuhan, China. JAMA Pediatr.2020;174(7):722-5. https://doi.org/10.1001/jamapediatrics.2020.0878

13. Kollias A, Kyriakoulis K, Dimakakos E, Poulakou G, Stergiou GS, Syrigos K. Thromboembolic risk and anticoagulant therapy in COVID-19 patients: emerging evidence and call for action. Br J Haematol. 2020;1894:846-7. https://doi.org/10.1111/bjh.16727

14. Whitehead CL, Walker SP. Consider pregnancy in COVID-19 therapeutic drug and vaccine trials. Lancet. 2020;395(10237):e92. https://doi. org/10.1016/S0140-6736(20)31029-1

15. Chu DK, AkI EA, Duda S, Solo K, Yaacoub S, Schünemann HJ. Physical distancing, face masks, and eye protection to prevent person-toperson transmission of SARS-CoV-2 and COVID-19: a systematic review and meta-analysis. Lancet. 2020;395(10242):1973-87. https://doi. org/10.1016/S0140-6736(20)31142-9

16. Davies NG, Kucharski AJ, Eggo RM, Gimma A, Edmunds WJ. Effects of non-pharmaceutical interventions on COVID-19 cases, deaths, and demand for hospital services in the UK: a modelling study. Lancet Public Health. 2020;5(7):375-85. https://doi.org/10.1016/ S2468-2667(20)30133-X

17. Tran NT, Tappis H, Spilotros N, Krause S, Knaster S. Not a luxury: a call to maintain sexual and reproductive health in humanitarian and fragile settings during the COVID-19 pandemic. Lancet Glob. Health. 2020;8(6):e760-1. https://doi.org/10.1016/ S2214-109X(20)30190-X

18. Center for Disease Control and Prevention. Interim Infection Prevention and Control Recommendations for Patients with Suspected or Confirmed Coronavirus Disease 2019 (COVID-19) pandemic [Internet]. Atlanta: Center for Disease Control and Prevention; 2020 [cited $2020 \mathrm{Jul}$ 01]. Available from: https://www.cdc.gov/coronavirus/2019-ncov/hcp/infection-control-recommendations.html?CDC_AA_ refVal=https\%3A\%2F\%2Fwww.cdc.gov\%2Fcoronavirus\%2F2019-ncov\%2Finfection-control\%2Fcontrol-recommendations.html

19. Royal College of Obstetricians and Gynaecologists (RGOG). Coronavirus (COVID-19) infection and pregnancy: information for healthcare professionals [Internet]. London: Royal College of Obstetricians and Gynaecologists; 2020 [cited 2020 Jul 01]. Available from: https://www. rcog.org.uk/ 
20. Rasmussen SA, Smulian JC, Lednicky JA, Wen TS, Jamieson DJ. Coronavirus Disease 2019 (COVID-19) and Pregnancy: what obstetricians need to know. Am J Obstet Gynecol. 2020;222(5):415-26. https://doi.org/10.1016/j.ajog.2020.02.017

21. Campion J, Javed A, Sartorius N, Marmot. Addressing the public mental health challenge of COVID-19. Lancet. 2020;7(8):657-9. https://doi. org/10.1016/S2215-0366(20)30240-6

22. Tong A, Sainsbury P, Craig J. Consolidated criteria for reporting qualitative research (COREQ): a 32-item checklist for interviews and focus groups. Int J Qual Health Care. 2007;19(6):349-57. https://doi.org/10.1093/intqhc/mzm042

23. Ministério da Economia (BR). Portaria n 65, de 16 de março de 2020 [Internet]. Diário Oficial da União, edição 52, seção 1, p. 27,2020 [cited $2020 \mathrm{Jul}$ 01]. Available from: http://www.in.gov.br/en/web/dou/-/portaria-n-65-de-16-de-marco-de-2020-248327812

24. Bardin L. Análise de conteúdo. Lisboa: Edições 70. 2011. 280 p.

25. Santos Filho SB, Souza KV. Metodologia para articular processos de formação-intervenção-avaliação na educação profissional em enfermagem. Ciênc Saúde Colet. 2020;25(1):79-88. https://doi.org/10.1590/1413-81232020251.28322019

26. Vasconcelos MFF, Nicolotti CA, Silva JF, Pereira SMLR. Políticas intermediárias (CEH - Educação Continuada em Saúde e PNH - Política Nacional de Humanização): rumo a uma forma de educar no / para o Sistema Nacional de Saúde (SUS). Interface (Botucatu). 2016;20(59):981-91. https://doi.org/10.1590/1807-57622015.0707

27. Ministério da Saúde (BR). Nota Técnica no 12/2020. Infecção COVID-19 e os riscos às mulheres no ciclo gravídico-puerperal[Internet]. Brasília: Ministério da Saúde; 2020 [cited 2020 Jul 01]. Available from: https://central3.to.gov.br/arquivo/505116/

28. Ministério da Saúde (BR). Recomendações n 22 de 09 de abril de 2020. Brasília: Ministério da Saúde; 2020 [cited 2020 Jul 01$]$. Available from: http://conselho.saude.gov.br/recomendacoes-cns/1112-recomendac-a-o-n-022-de-09-de-abril-de-2020

29. Walker PGT, Whittaker C, Watson OJ, Baguelin M, Winskill P, Hamlet A, et al. The impact of COVID-19 and strategies for mitigation and suppression in low- and middle- income countries. Science. 2020;369(6502) 413-22. https://doi.org/10.1126/science.abc0035

30. Mamede MV. Força de trabalho de enfermagem e obstetrícia e os novos Objetivos de Desenvolvimento Sustentável (2016-2030). Rev Rene [Internet]. 2017 [cited 2020 Jul 01];18(6):710-11. Available from: http://periodicos.ufc.br/rene/article/view/31068/71659

31. Hussein J. COVID-19: What implications for sexual and reproductive health and rights globally? Sex Reprod Health Matters. 2020;28(1):1-3. https://doi.org/10.1080 / 26410397.2020.1746065

32. Merhy EL. Educação Permanente em movimento: uma política de reconhecimento e cooperação, ativando os encontros do cotidiano no mundo do trabalho em saúde, questões para os gestores, trabalhadores e quem mais quiser se ver nisso. Saúde Redes. 2015;1(1):7-14. https://doi.org/10.18310/2446-4813.2015v1n1p07-14

33. Ministério da Saúde (BR). Política Nacional de Humanização. Formação e intervenção [Internet]. 2010 [cited 2020 Jul 01]. Available from: http://bvs.saude.gov.br/bvs/publicacoes/cadernos_humanizaSUS.pdf

34. Ministério da Saúde (BR). Painel Coronavírus [Internet]. Brasília: Ministério da Saúde; 2010 [cited 2020 Jul 01]. Available from: https://covid. saude.gov.br/

35. Conselho Federal de Enfermagem (COFEN). Observatório da Enfermagem[Internet]. Brasília: Conselho Federal de Enfermagem; 2020 [cited 2020 Jul 01]. Available from: http://observatoriodaenfermagem.cofen.gov.br/ 